\title{
Relationship Between Stock Index And National Economy In India: An Empirical Analysis
}

\author{
P K Mishra \\ Associate Professor in Economics \\ Central University of Punjab, Mansa Road, Bathinda-151001
}

\begin{abstract}
It has been accepted that developed capital markets are able to mobilize domestic savings and able to allocate funds more efficiently. Thus, stock markets can play a role in inducing economic growth in emerging market economies like India. Thus, this paper is an attempt to investigate the causal relationship between the stock index and the national economy in the context of India over the period 2006 to 2015 using the Toda-Yamamoto approach. The empirical findings provide the evidence of unidirectional causality running from real economic growth to stock market in India over the entire observation period. This finding is significant for the policy makers of the country. Plans and policies should be formulated such that the demand side factors are made influential. This would necessitate higher resource mobilization and thus, contribute to the development of stock market of the country.
\end{abstract}

Keywords: India, Stock Market, Real economic Growth, Causality, Toda-Yamamoto Approach

\section{Introduction}

The Indian stock market though one of the oldest in Asia and even older than New York stock exchange being in operation since 1875 , remained largely outside the global integration process until the late 1980s. And, the reform of Indian stock market began with the establishment of Securities and Exchange Board of India (SEBI) in 1988. However, the reform process gained momentum only in the aftermath of the external payments crisis of 1991 followed by the securities scam of 1992 . Among the significant measures of integration, portfolio investment by Foreign Institutional Investors (FIIs) allowed since September 1992 has been the turning point for the Indian stock market. Following the commissioning of the National Stock Exchange (NSE) in June 1994, National Securities Clearing Corporation Ltd. (NSCC) in April 1996 and National Securities Depository Ltd. (NSDL) in November 1996, a screen-based, anonymous, order-driven online dematerialized trading has been the order of the day coupled with improved risk management practices for clearing and settlement.

Indian capital market has undergone tremendous transformations since 1991, when the government has adopted liberalization and globalization more seriously than ever before. As a result, there can be little doubt about the growing importance of the stock market from the point of view of the aggregate economy. It has been observed that Indian capital market has been evolved as a major source of raising resources for Indian corporate sector. Despite the slowdown during 2008-09, today, Indian capital market features a developed regulatory environment, a modern market infrastructure, a steadily increasing market capitalization and liquidity, better allocation and mobilization of resources, a rapidly developing derivatives market, a robust mutual fund industry, and increased issuer transparency.

In the primary market, the total resources mobilized through the issuance of securities by corporate and government in 2014-15 increased 
ABBS Financial Markets

by 10.5 per cent as compared to $2013-14$, to Rs.14,479 billion from Rs.13,097 billion. Resource mobilisation by corporates in the primary market rose by $13 \%$ in $2014-2015$ to Rs.4,659 billion. This rise was driven by an increase in the resources mobilised through the private placement route; the capital raised through private placement went up by $12 \%$ to Rs.4,465 billion. However, the resources mobilised through public issues witnessed a drop of $26 \%$ to Rs. 98 billion, accounting for a mere $1 \%$ of the total resources mobilised domestically. Private placement accounted for $98 \%$ of the domestic total resource mobilisation by the corporate sector. Resource mobilisation through Euro Issues surged significantly to Rs.96 billion in 2014-2015 from a mere Rs. 1 billion in 2013-2014. The resources raised by Indian corporates from the international capital market through the issuance of Foreign Currency Convertible Bonds (FCCBs), GDRs, and ADRs recovered from the downward trajectory in 2013-2014. Indian corporate raised Rs.96 billion from international capital markets in 2014-2015, as against Rs. 1 billion in the previous year. Compared to 2013-2014, the share of resources raised by Indian corporates from the international capital market surged from almost nil in 20132014 to $1 \%$ in 2014-2015. The sudden surge in the resources mobilised through Euro issues was partly driven by the improved investor sentiment in view of the future prospects of the Indian economy.

In 2014-2015, the resources mobilised from public and rights issue decreased, unlike in the previous year. In particular, the capital raised from public and rights issue fell by $66 \%$ (compared to the $71 \%$ increase in 2013-2014) to Rs.192 billion. This was mainly driven by a $76 \%$ fall in the resources mobilised through public issues, which fell from Rs.511 billion in 2013-2014 to Rs. 125 billion in 2014-2015. However, the amount raised through rights issue (which increased from Rs.46 billion in 2013-2014 to Rs.68 billion in 20142015) partially offset the decline in the total resources mobilised from public and rights issue. The mobilisation of resources through rights issues recorded an increase of 48\% in 2014-2015, following a 48\% drop in 2013-2014. Resource mobilisation through rights issue increased from Rs.46 billion in 2013-2014 to Rs.68 billion in 2014-2015. In 2014-2015, the number of companies using the rights route to raise capital was 18 (as against 15 in the previous year).

In the primary debt market, the government and the corporate sector collectively raised a total of Rs.14,244 billion from the primary market in 2014-2015 which is an increase of 18 percent as compared to a decline of 2 percent in the preceding year. About 69 percent of the resources were raised by the government (the central and the state governments), while the balance was mobilized by the corporate sector through public and private placement issues. The corporate sector showed an increase of 41 percent in the primary market borrowings. The turnover in the secondary debt market in 2014-15 aggregated Rs. 1,83,191 billion, 11 percent higher than that in the previous fiscal year.

Similar to the previous years, government borrowing in the secondary market accounted for more than 98 percent of the total secondary market borrowings. In the government securities market, the aggregate trading volumes in central and state government-dated securities on Subsidiary General Ledger (SGL) increased from Rs.8,971 billion in FY 2014 to Rs.9,820 billion in FY 2015.

In the secondary market, the market capitalisation of NSE and BSE has surged by $37 \%$ in the past 1 year. The turnover of the cash segment of stock exchanges across India has increased by 55\% from 2013-2014 to 2014-2015.

India's experience with the equity derivatives market has been extremely positive. The turnover of derivatives on the NSE increased from Rs.24 billion in 2000-2001 to Rs.3,13,497 billion in 20112012, and further to Rs.3,82,114.1 billion in 2013-2014. In 2014-2015, the figure reached 
ABBS $\quad$ Financial Markets

Rs. $5,56,064.5$ billion, maintaining a continuous upward trend. In the derivatives market, the equity derivatives market turnover on the Indian exchanges increased from Rs.4,74,308 billion in FY 2014 to Rs.7,59,692 billion in FY 2015. Currency derivatives trading in India was started in August 2008 at NSE with currency futures on the underlying USD-INR exchange rate, followed by future trading in currency pairs such as GBP-INR, EURO-INR, and JPY-INR. Later, in October 2010, currency options trading were allowed on USD-INR. The currency derivatives trading turnover (Rs.56,345.6 billion) in India declined by 19\% in 2014-2015 as compared to a year ago.

The monthly trend in FII investments in 20142015 shows that the net FII investments were positive for all the months, which reflects the positive investor sentiment and the growing affinity for India as a popular investment destination. The net FPI investments surged four times in 20142015 compared to the numbers in 2013-2014.

The total market capitalization at BSE as a percentage of India's real Gross Domestic product (GDP) has increased from $49 \%$ in $1990-91$ to around $138 \%$ in $2009-10$. Similarly the total market capitalization at NSE as a percentage of India's real Gross Domestic product has increased from $35 \%$ in $1994-95$ to $114 \%$ in $2009-10$. Thus, not only has the stock market increased relative to the real economy, but also it appears that the inter-relationship between them has strengthened. It has always been recognized all over the world that the stock market reflects to some extent the activities in the rest of the economy, but recently there has been widespread recognition that the influence is also in the opposite direction - dramatic events in the stock market are likely to have an impact upon the real economy. Therefore, the most sought after issue is now 'should the national economy lead the stock market or the other way around? This paper is an attempt to investigate the dynamics of the relationship between the stock index and the national economy in the case of India for the period 2006 through 2015.

\section{Literature Review}

The relationship between stock market and real economic growth of developing and developed nations has been widely studied, but the extant literature provides the evidence of mixed results. Some studies conclude about the positive relationship between capital market development and real economic growth, while others point to no relationship between them. Levine \& Zervos (1996) and Beck \& Levine (2004) found a strong and positive correlation between stock market development and economic growth. This finding is also supported by an extended study by Levine and Zervos (1998) which concludes that stock market liquidity and future economic growth rate, rate of capital accumulation and output growth rate were positively correlated with each other. Agarwal (2000) and Nieuwerburgh et al. (2005) supports the findings of Levine \& Zervos (1996, 1998). Bader \& Qarn (2005) argued that financial development leads to real economic growth of a nation either through increasing investment efficiency or through increasing resources for investment.

In the context of India, Biswal \& Veerashekharappa (2002) argues that the stock market development plays a significant role in the economic growth process of the country. Agrawalla and Tuteja (2007) found that a stable long-run equilibrium relationship between stock market development and economic growth in India is fostered by transparent and efficient stock markets. Similarly, Pradhan (2007) advocated that a well-developed stock market could enhance economic activity in an emerging market economy like India, and the findings of Deb and Mukherjee (2008), Pal \& Mittal (2011) and Kumar (2014) corroborate to it.

While distinguishing between the short-run and long-run causality effects, Naik and Padhi (2012) provide the evidence of the existence of long-run (but not the short-run) equilibrium relationship between the macroeconomic variables and stock market development. In a similar study, Ted et al 
ABBS $\quad$ Financial Markets

(2005) found no evidence of association between the Indian stock market development and economic growth in the entire period observation; the evidence is that stock market development was relevant for economic development during pre-liberalization era, but not in the post-liberalization period. Chakraborty (2010) found no support to the theoretical prediction that the stock market development plays an important role in enhancing economic growth in India in the post-reform period. In the case of Egypt, Badr (2015) found no causal relationship between stock market development and economic growth.

Thus, a mixed empirical evidence is provided by the finance literature concerning the relationship between capital market development and real economic growth of a country. Theoretical arguments however, always predict a positive relationship between financial market development and economic growth (Mishra \& Pradhan, 2011; Mishra, 2015). This relationship may be supply leading and/or demand driven. Thus, an investigation of the lead-lag relationship between financial market development and real economic growth in a multivariate time-series framework is warranted. It is with this backdrop, this paper is an attempt to investigate the dynamics of the causal relationship between the stock market development and the growth of national economy for India over an observation period spanning from 2006 through 2015.

\section{Data and Methodology}

The very objective of this study is to explore the dynamics of the causal relationship between the stock market and the real national economy in the context of the emerging market economy like India over the sample period 2006 to 2015 . This paper uses India's Real GDP as the variable of macroeconomic performance, and BSE Sensex and S \& $P$ CNX Nifty as the representative of Indian stock market movements. The study uses quarterly data for the sample period. All the data have been collected from different volumes of the Handbook of Statistics on Indian Economy, published by
Reserve Bank of India on an annual basis. The time series are then expressed in their log forms. Thus, the variables of the study are GDP, SNX and NTY. The study uses the Toda-Yamamoto method of studying the causal relationship between stock index and the national economy in the case of India.

The Toda and Yamamoto (1995) method of Granger causality test is relatively more efficient in small sample data sizes and is particularly appropriate for time series for which the order of integration is not known or may not be necessarily the same, or the order of integration is more than two. Another advantage of this procedure is that it does not require the pre-testing of the time series for cointegration properties so long as the order of integration of the process does not exceed the true lag length of the model. Toda and Yamamoto (1995) methodology of Granger causality test by directly performing the test on the coefficients of the levels VAR, minimises the risk associated with possibly wrongly identifying the orders of integration of the series and the presence of cointegration relationship (Galies, 1997; Mavrotas and Kelly, 2001).

The basic idea in the Toda and Yamamoto (1995) procedure is artificially augmenting the correct VAR order, $k$ with $d$ extra lags, where is the maximum likely order of integration of the time series in the empirical system. Thus, at the outset, it is required to determine the maximum order of integration of time series, say, . Then the optimal lag length of the VAR model is to be determined using Akaike Information Criteria (AIC), say, . In the third step, the ()$^{\text {th }}$ order of VAR is to be estimated with Seemingly Unrelated Regression(SUR). At last, the null hypothesis of no-causality is to be tested using a standard Wald statistic, say, . The implementation of the Toda and Yamamoto approach to Granger causality necessitates linking the three variables of the study in a trivariate system as follows: 
ABBS Financial Markets

$Y_{t}=A_{0}+A_{1} Y_{t-1}+\ldots \ldots+A_{k} Y_{t-k}+\varepsilon_{t} \ldots \ldots \ldots$

Where $Y_{t}=\left[\begin{array}{c}Y_{1 t} \\ Y_{2 t} \\ Y_{3 t}\end{array}\right]=\left[\begin{array}{c}G D P_{t} \\ S N X_{t} \\ N T Y_{t}\end{array}\right]$ and $\varepsilon_{t} \sim$ i.i.d $N(0, \mu)$

and A's are $3 \times 3$ matrices of coefficients.

The following augmented levels $\operatorname{VAR}(p=k+d)$ shall be estimated to test the null hypothesis of no-causality:

$Y_{t}=\alpha+A_{1} Y_{t-1}+\ldots . .+A_{k} Y_{t-k}+A_{k+1} Y_{t-k-1}+\ldots . .+A_{p} Y_{t-p}+\varepsilon_{t}$. .......(2)

This augmented VAR system is to be estimated using the Seemingly Unrelated Regression (SUR) technique. The null hypotheses of the study are:

$H_{01}: Y_{1 t}$ does not cause $Y_{2 t}$ : GDP does not cause SNX

$\mathrm{H}_{02}: \mathrm{Y}_{2 \mathrm{t}}$ does not cause $\mathrm{Y}_{1 \mathrm{t}}$ : SNX does not cause GDP

$H_{03}: Y_{1 \mathrm{t}}$ does not cause $\mathrm{Y}_{3 \mathrm{t}}$ : GDP does not cause NTY

$H_{04}: Y_{3 t}$ does not cause $Y_{1 \mathrm{t}}$ : NTY does not cause GDP

These null hypotheses are to be tested by Wald test which can be formulated as follows:

Let $e_{3}=\left[\begin{array}{l}0 \\ 0 \\ 1\end{array}\right], e_{1}=\left[\begin{array}{l}1 \\ 0 \\ 0\end{array}\right]$ and $D=I_{k} \otimes e_{3}$ with $I_{k}$ being

the $k \times k$ identity matrix. Let

be the column vector obtained by stacking the rows of the matrix $A$. Then the Wald Test statistic is given by: $W=T\left(\left(e_{1}^{\prime} \otimes D^{\prime}\right) \operatorname{vec}(\hat{A})\right)\left(\left(e_{1}^{\prime} \otimes D^{\prime}\right) \hat{\Sigma}\left(e_{1}^{\prime} \otimes D^{\prime}\right)^{\prime}\right)^{\prime}\left(e_{1}^{\prime} \otimes D^{\prime}\right) \operatorname{vec}(\hat{A})$ where $\hat{\Sigma}_{\Sigma}$ is a consistent estimator of the asymptotic variance matrix of $\sqrt{T}$ vec $(\hat{A}-A)$
The Wald test statistic ( $W$ )has an asymptotic $\chi^{2}$ distribution with $k$ degrees of freedom. The reason for ignoring the remaining $d_{\max }$ autoregressive parameters in testing for Granger causality is that it helps overcoming the problem of non-standard asymptotic properties associated with standard Wald test for integrated variables. It has been shown that Wald test experience efficiency improvement when SUR models are used in the estimation (Rambaldi and Doran, 1996).

\section{Analysis and Discussion}

At the outset, the Pearson's correlation coefficient matrix between variables has been calculated over the sample period and its significance has been tested by the t-test. The results are presented in Table-1. The correlation matrix reports positive and high degree correlation between variables. Furthermore, such positive correlations are significant at 5\% level. Correlations, however, do not say anything about causal relationship and thus, leaves unsettled the debate concerning the causal relationship between stock market indices and real economic growth in India.

Table 1: Correlation Matrix

\begin{tabular}{|l|c|c|c|}
\hline Variables & GDP & SNX & NTY \\
\hline GDP & 1 & 0.85 & 0.85 \\
\hline SNX & - & 1 & 0.99 \\
\hline NTY & - & - & 1 \\
\hline
\end{tabular}

Source: Author's Own Calculation

In the first step of the causality analysis, the order of integration for each of the three variables used in the analysis has been determined. The Augmented Dickey-Fuller (ADF) unit root test has been used for this purpose. The results of ADF unit root test are reported in Table -2. It is quite clear that the hull hypothesis of no unit roots for GDP is rejected at its level form since the ADF test statistic value is less than the critical values at $10 \%$ levels of significance. Thus, this variable is stationary and integrated of order 0 , i.e., I(0). But the variables SNX and NTY are both integrated of order one, i.e., I(1) as the ADF test statistics at 
ABBS $\quad$ Financial Markets

the first difference form for them are less than the critical values at $5 \%$ level of significance.

Table 2: Results of Unit Root Test

\begin{tabular}{|c|c|c|c|c|c|c|c|}
\hline \multicolumn{8}{|c|}{ ADF test statistic } \\
\hline \multirow{2}{*}{\begin{tabular}{|l} 
VARIABLES \\
GDP
\end{tabular}} & \multicolumn{2}{|c|}{$\begin{array}{l}\text { Level form with } \\
\text { intercept and linear } \\
\text { trend }\end{array}$} & \multicolumn{2}{|c|}{$\begin{array}{l}\text { First Difference form } \\
\text { with intercept and } \\
\text { linear trend }\end{array}$} & \multicolumn{2}{|c|}{$\begin{array}{l}\text { Second Difference form } \\
\text { with intercept and } \\
\text { linear trend }\end{array}$} & $\begin{array}{c}\text { Order of } \\
\text { Integration }\end{array}$ \\
\hline & -3.33 & $\begin{array}{c}5 \%:-3.63 \\
10 \%:-3.25\end{array}$ & NA & NA & NA & $\mathrm{NAl}$ & (0) \\
\hline SNX & -2.58 & $\begin{array}{c}1 \%:-4.35 \\
5 \%:-3.59 \\
10 \%:-3.23\end{array}$ & -3.42 & $\begin{array}{c}1 \%:-4.35 \\
5 \%:-3.59 \\
10 \%:-3.23\end{array}$ & NA & NA & I(1) \\
\hline NTY & -2.60 & $\begin{array}{c}1 \%:-4.35 \\
5 \%:-3.59 \\
10 \%:-3.23\end{array}$ & -3.56 & $\begin{array}{c}11 \%:-4.35 \\
5 \%:-3.59 \\
10 \%:-3.23\end{array}$ & NA & NAI & (1) \\
\hline
\end{tabular}

Source: Author's Own Calculation

Thus, the results obtained from the ADF test suggest that the maximum order of integration of the series under study is two, i.e., $d_{\max }=1$. Therefore, the Toda-Yamamoto test involves the addition of one extra lag of each of the variables to control for potential Cointegration. Then, it is required to select the appropriate lag length for the VAR in order to perform causality test. In this study, the Akaike Information Criterion (AIC) and Final Prediction Error (FPE) techniques are used to determine the optimal lag length. In small sample study $(n<60)$, AIC and FPE are superior to other information criteria (Lutkepohl, 1991; Liew, 2004). The results of such test are presented in Table-3. The optimal lag length, thus selected is $k=2$.

Table 3: Selection of Lag Length

\begin{tabular}{|ccc|}
\hline Lag & FPE & AIC \\
\hline 0 & 0.000000351 & -6.349837 \\
\hline 1 & 0.00000000909 & -10.00940 \\
\hline 2 & $0.00000000651^{*}$ & $-10.37695^{\star}$ \\
\hline
\end{tabular}

*indicates lag order selected by the criterion at $5 \%$ level

Source: Author's Own Calculation

In the next step, the augmented VAR of order $3\left(p=k+d_{\max }\right)$ is estimated with Seemingly Unrelated Regression (SUR) and the Wald test is carried out using standard chi-square distribution. And, the results of Toda and Yamamoto Ganger non-causality test are reported in Table-4. 
ABBS Financial Markets

Table 4: Results of Toda-Yamamoto Granger Non-Causality Test

\begin{tabular}{|lccc|}
\hline Null Hypothesis & Chi-Square statistic(d.f) & $\mathrm{p}$-Value & Decision \\
\hline GDP does not Granger Cause SNX & $12.00074(3)$ & 0.0074 & Reject \\
\hline SNX does not Granger Cause GDP & $2.6658(3)$ & 0.4461 & Accept \\
\hline GDP does not Granger Cause NTY & $11.613(3)$ & 0.0088 & Reject \\
\hline NTY does not Granger Cause GDP & $2.719(3)$ & 0.4369 & Accept \\
\hline
\end{tabular}

Source: Author's Own Calculation

The results show that the null hypotheses that 'GDP does not Granger Cause SNX' and 'GDP does not Granger Cause NTY' are rejected at 5\% level of significance. This means GDP causes SNX and NTY, i.e., unidirectional causal relationship holds between real economic growth and stock market in India over the sample period. In other words, real economic growth spurs stock market development in the country. Furthermore, the null hypotheses that 'SNX does not Granger Cause GDP' and 'NTY does not Granger Cause GDP' are accepted at $5 \%$ level of significance. This means stock market movements do not lead to real economic growth of the country.

Therefore, it is inferred that real national economy of India is very important in influencing the stock market activities. It is the strong fundamentals of the real national economy that leads to such positive effect on the capital market. Perhaps, this is the reason why Indian capital market could saw quick recovery from the clutches of global financial slowdown. It may thus, be stated that the stock markets in India are demand driven and output led which means that demand for greater equity finance is led by higher growth rate of national output. That is, the state of the economy has a bearing on the share prices, but the health of the stock market in the sense of a rising share price index is not reflective of an improvement in the health of the economy. In other words, a bull run or rising prices in the stock market cannot be taken to be a leading indicator of the revival of the economy in India. This finding has important implications for policy makers.

Expansion in national output always exerts tangible multiplier effects on income and employment. This will cause increase in purchasing power and thus, aggregate demand will increase which in turn will call for greater investment and higher production thereby demanding greater mobilization of financial resources in the economy. Such an expansionary economic environment, although sometimes inflationary, would lead to stock market development. Therefore, the policy makers should devise prudential norms to facilitate sustainable growth of the producing sectors, and resource mobilizing intermediaries in the country.

\section{Concluding Remark}

Financial markets have been well recognized in providing efficient access to capital required by business houses thereby influencing not only the financial health of firms but in a significant way their real productivity. Such productivity gains again not only contribute to individual profit gains, but in a larger sense the development of other sectors together constituting the entire macro-economy of a nation. Thus, it is worthy to take up a study examining the causal relationship between the stock market development (i.e., the stock index movements) and the national economy in the case of India for the period spanning from 2006 through 2015. The Pearson's correlation coefficient indicates the existence of a positive and high degree of correlation between the stock market movements and real national economy in India. Correlation, however, does not say anything about causal relationship and thus, 
leaves the debate unsettled. So, the causal relationship has been examined by the TodaYamamoto approach. The results provide the empirical evidence of unidirectional causality from real economic growth to stock market in India over the sample period. This finding is very important for the policy makers of the country. Plans and policies should be formulated such that the demand side factors are made influential. This would necessitate higher resource mobilization and thus, contribute to the development of stock market of the country.

\section{References}

Agarwal, R. N. (2000): Capital Market Development, Corporate Financing Pattern and Economic Growth in India, Working Paper, IEG, New Delhi, India, pp.1-19.

Agrawalla, R. K., \& Tuteja, S. K. (2007): Causality Between Stock Market Development and Economic Growth: A Case Study of India, Journal of Management Research, 7(3): 158-168.

Bader, S., \& Qarn, A. S. (2005): Financial Development and Economic Growth: The Time Series Evidence from Egypt. Discussion Paper No. 05-14, Ben Gurion University

Badr, O.M., (2015): Stock Market Development and Economic Growth: Evidences from Egypt, International Journal of Trade, Economics and Finance, 6(2): 96-101

Beck, T. \& Levine, R. (2004): Stock Markets, Banks and Growth: Panel Evidence. Journal of Banking and Finance, 28, 423-442.

Biswal , P. C. and Veerashekharappa (2002): Stock Market Development and Economic Growth in India, Indian Journal of Economics, Vol. LXXXII, No. 327.

Chakraborty, I. (2010): Financial Development and Economic Growth in India: An Analysis of the Postreform Period, South Asia Economic Journal, 11(2): 287-308
Deb, S. G., \& Mukherjee, J. (2008). Does stock Market Development Cause Economic growth? A Time Series Analysis for Indian Economy. International Research Journal of Finance and Economics, 21, 42-149.

Giles, D. (1997): Causality between the Measured and Underground Economies in NewZealand, Applied Economics Letters, 4, 63-67.

Kumar, R., (2014): Macro Economy and Stock Market Performance in India: An Econometric Analysis, IJEAR, 4(2): 9-18

Levine, R., \& Zervos, S. (1998). Stock Market Development and Long-Run Growth", World Bank Economic Review, 10(2): 323-339

Levine, R., \& Zervos, S. (1998). Stock Markets, Banks and Economic Growth. American Economic Review, 88(3): 537-558.

Levine, Ross, and Zervos, Sara (1996): Stock Market Development and Long-Run Growth, The World Bank Policy Research Working Paper No. 1582, The World Bank

Liew, V.K.S. (2004): Which Lag Length Selection Criterion Should We Employ? Economics Bulletin, 3(33): 1-9.

Lutkepohl, H. (1991): Introduction to Multiple Time Series Analysis, Germany: Springer-Verlag.

Mavrotas, G. and Kelly, R. (2001): Old Wine in New Bottles: Testing Causality between Savings and Growth, The Manchester School, 69, 97-105.

Mishra, P. K., and Pradhan, B. B., (2011): Financial Development and Economic Growth in India: An Empirical Analysis, International Journal of Business and Information Technology, 1(1): 97108

Mishra, P.K. (2015): Role of Capital Market Development in the Economic Growth of India, in Contemporary Issues in Business and Management, edited by Pavnesh Kumar, Himalaya Publishing House Pvt. Ltd., New Delhi, India, pp.135-146 
Naik, P. K., and Padhi, P. (2012): The Impact of Macroeconomic Fundamentals on Stock Prices Revisited: Evidence from Indian Data, Eurasian Journal of Business and Economics, 5(10): 2544

Nieuwerburgh, S. V., Buelens, F., \& Cuyvers, L. (2005). Stock Market Development and Economic Growth in Belgium. Working Paper No. FIN-05024, New York University.

Padhan, P. C. (2007): The Nexus between Stock Market and Economic Activity: An Empirical Analysis for India, International Journal of Social Economics, 34(10): 741 - 753
Pal, K. and Mittal, R. (2011): Impact of Macroeconomic indicators on Indian Capital Markets, Journal of Risk Finance, 12(2): 84-97

Rambaldi, A. N. And Doran, T. E. (1996): Testing for Granger Non-Causality in Cointegrated System Made Easy, Working Papers in Econometrics and Applied Statistics No. 88, Department of Econometrics, University of New England.

Ted, A., Lazar, D., \& Jeyapaul, J. (2005). Is the Indian Stock Market A Casino?. Journal of Business and Economic Research, 3(4): 63-72.

Toda, H.Y. and T. Yamamoto. (1995): Statistical Inference in Vector Auto-Regressions with Possibly Integrated Processes, Journal of Econometrics, 66, 225-250. 